\title{
An unusual complication following saphenous vein graft harvesting for coronary artery bypass surgery: Pseudo-Kaposi sarcoma
}

\author{
Koroner arter baypas cerrahisi için safen ven greft hazırlama sonrasında alışılmadık bir komplikasyon: \\ Psödo-Kaposi sarkomu \\ Şahin Şahinalp' 1 (D), İbrahim $\operatorname{Aras}^{2}$ (1) \\ 'Department of Cardiovascular Surgery, Yüzüncü Yıl University Faculty of Medicine, Van, Turkey \\ 2Department of Pathology, Yüzüncü Yıl University Faculty of Medicine, Van, Turkey
}

\begin{abstract}
Pseudo-Kaposi sarcoma is a rare, vasoproliferative skin disease usually caused by an underlying vascular malformation or venous insufficiency. Unusual forms such as amputation stumps and lower extremity paralysis have been also reported. However, its emergence in the leg from which the saphenous vein was harvested following peripheral artery disease and coronary artery bypass surgery has not been previously reported. We, herein, present a 78-year-old female case who developed pseudoKaposi syndrome in her left leg, which was affected by peripheral artery disease following the removal of the saphenous vein six months after coronary artery bypass grafting.
\end{abstract}

Keywords: Acroangiodermatitis, coronary artery bypass grafting, pseudo-Kaposi sarcoma, saphenous vein harvesting.

Complications which may develop after open heart surgery are often well-documented in the literature. Complications in the early period of coronary artery bypass grafting (CABG) after removal of the saphenous vein include color changes and wound healing problems in the affected leg, while those occurring in the late period include edema in the legs, permanent color changes, and stasis findings. ${ }^{[1,2]}$

Pseudo-Kaposi sarcoma (PKS), also known as acroangiodermatitis, is a rare vasoproliferative dermatological disease of unknown etiology. Lesions usually appear in the lower extremities as limited, slowly-growing, red or dark-colored macules, papules or plaques. Until now, two types of chronic venous

\section{$\ddot{O} Z$}

Psödo-Kaposi sarkomu genellikle altta yatan vasküler malformasyon veya venöz yetmezlik sonucu ortaya çıkan nadir, vazoproliferatif bir cilt hastalığıdır. Ampütasyon güdüğgu ve alt ekstremite paralizisi gibi alışılmadık formlar da bildirilmiştir. Ancak, periferik arter hastalığı ve koroner arter baypas cerrahisi sonrası safen ven çıkarılan bacakta ortaya çıkışı, şimdiye kadar bildirilmemiştir. Bu yazıda, koroner arter baypas greftlemeden altı ay sonra safen ven çıkarılmasını takiben perifer arter hastalığından etkilenen, sol bacağında psödo-Kaposi sendromu gelişen 78 yaşında bir kadın olgu sunuldu.

Anahtar sözcükler: Akroanjiodermatit, koroner arter baypas greftleme, psödo-Kaposi sarkomu, safen ven çıkarılması.

insufficiency and arteriovenous malformation have been described. ${ }^{[3]}$ The development of PKS has been also associated with conditions such as paralysis, congenital myopathy, and amputation. ${ }^{[4]}$ A single report in the literature showed that a patient with PKS experienced worsening of lesions in the leg following saphenous vein removal due to $\mathrm{CABG}^{[3]}$ However, there are no reports of new-onset PKS following CABG in the literature.

In this article, we present a case with diffuse skin lesions in her leg six months after saphenous vein harvesting for CABG in whom the diagnosis was reported as PKS.

Received: December 09, 2019 Accepted: January 13, 2020 Published online:April 22, 2020

Correspondence: Şahin Şahinalp, MD. Yüzüncü Yı Üniversitesi Tıp Fakültesi, Kalp ve Damar Cerrahisi Anabilim Dalı, 65080 Van, Türkiye. Tel: +90 432 - 2150470 / 6112 e-mail: ssahinalp@gmail.com

Cite this article as:

Şahinalp Ș, Aras I. An unusual complication following saphenous vein graft harvesting for coronary artery bypass surgery: Pseudo-Kaposi sarcoma. Turk Gogus Kalp Dama 2020;28(2):382-385 


\section{CASE REPORT}

A 78-year-old female patient was admitted with a history of diabetes, hypertension, and hyperlipidemia who underwent $\mathrm{CABG}$ nine months previously. The patient presented with an itchy rash on her left leg which started three months ago, the intensity of which subsequently increased. On her physical examination, purple-colored papules and plaques, the largest of which was $10 \mathrm{~cm}$ in diameter, were detected in the knee joint and more prominently at the back of the left foot (Figure 1). A pulse examination of the left leg was performed, and the pulses were found to be non-palpable. The temperature of the left foot and leg was found to be increased. Routine laboratory tests, however, revealed no unexpected results. Doppler ultrasound failed to detect deep vein thrombosis and no reflux flow was observed, as an indicative of superficial and deep venous insufficiency. Digital subtraction angiography of the lower extremity revealed a totally occluded left external iliac artery with occluded main femoral and distal arteries through collateral vessels (Figure 2). No arteriovenous malformation or fistulas were detected.

The patient's skin lesions were evaluated by a dermatologist. A skin biopsy revealed capillary vascular proliferation and erythrocyte extravasation in the dermis (Figure 3). Immunohistochemical analysis revealed CD34 staining in the endothelial cells, but not in the perivascular spaces. Based on these results, the lesion was reported as PKS. Topical steroid treatment was initiated by the dermatologist, and an $8 \times 10-\mathrm{mm}$ stent was applied to the left external iliac artery to remove the occlusion. In addition to topical

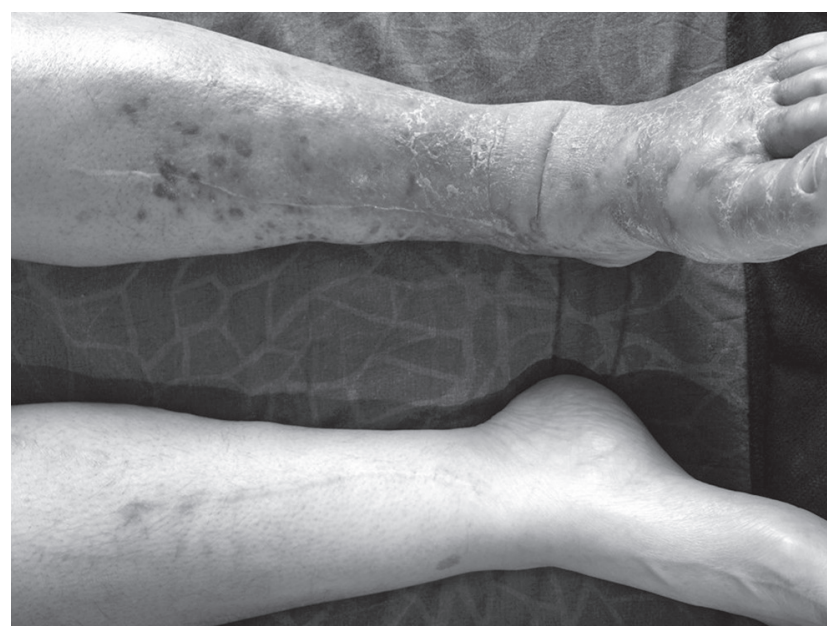

Figure 1. Diffuse skin lesions affecting leg undergoing saphenous vein removal (first presentation). steroid treatment, the patient was discharged with prescriptions for acetylsalicylic acid $100 \mathrm{mg}$ once daily and clopidogrel $75 \mathrm{mg}$ once daily to be ingested orally.

At six months of follow-up, itching completely resolved and infiltrated papules and plaques significantly regressed (Figure 4). Upon examination, the pulses were found to be palpable.

A written informed consent was obtained from the patient.

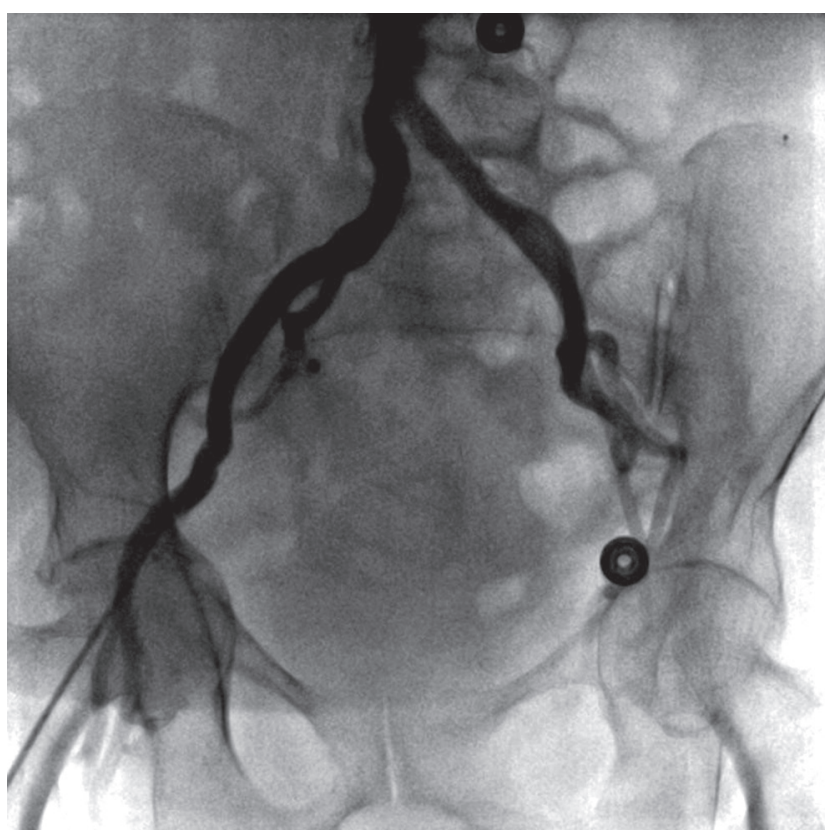

Figure 2. Digital subtraction angiography: Totally occluded left external iliac artery.

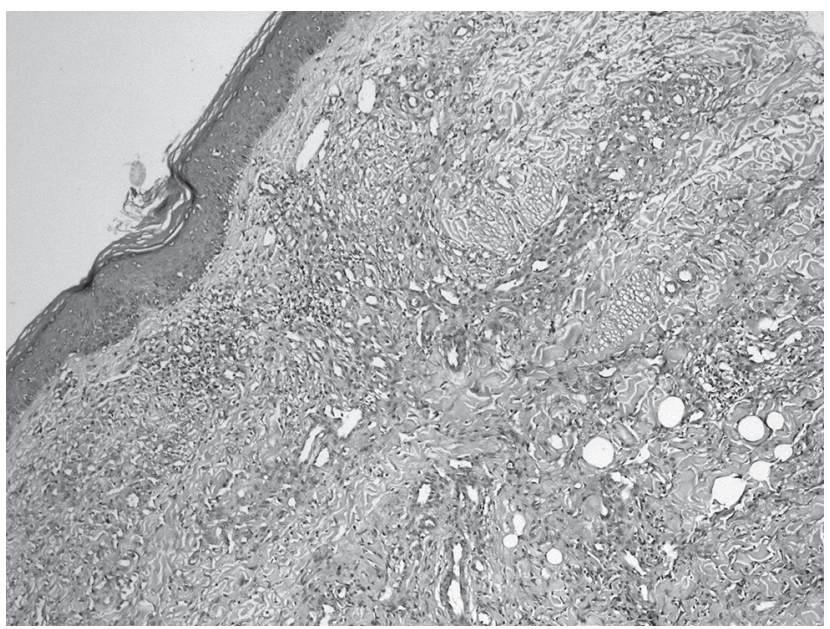

Figure 3. Extravasated erythrocytes in dermis, hemosiderin deposition, lobular proliferation of capillary vessels, and mild lymphocytic inflammation perivascular $(\mathrm{H}-\mathrm{E} \times 100)$ 


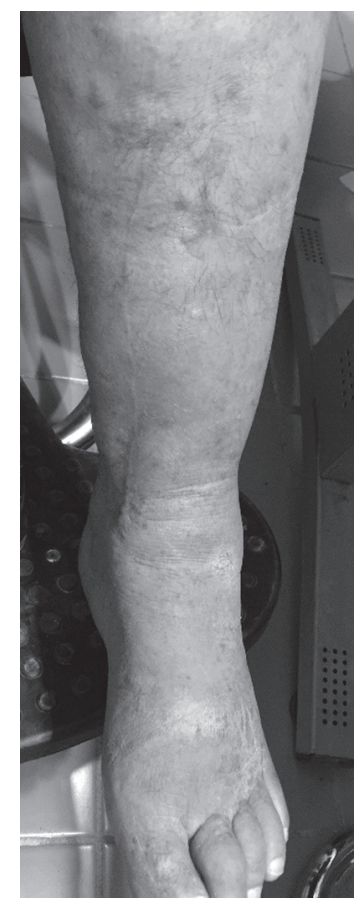

Figure 4. Control image at six months after treatment.

\section{DISCUSSION}

The case presented herein is an unusual instance of emergence and etiopathogenesis of PKS after open heart surgery. Alshihry et al ${ }^{[3]}$ previously reported a patient with PKS whose lesions worsened following CABG. However, there is no case report in the literature of new-onset PKS after CABG.

A condition of unknown origin such as PKS may result from a number of reasons after a procedure as complex as open heart surgery. Several factors, including extracorporeal circulation and subsequent inflammatory process, medications used, and particularly trauma to the leg from which the saphenous is harvested, may be involved in the development of PKS. Although chronic venous insufficiency and arteriovenous malformation may both play a role in $\mathrm{PKS}{ }^{[3]}$ there were no such clinical findings in our case. Some authors have suggested that, in patients with arteriovenous malformation, fibroblast proliferation and neovascularization after hyperperfusion and exposure to high oxygen concentration ${ }^{[5]}$ may play a role in the development of PKS. However, in this case, while there was no arteriovenous malformation, PKS was accompanied by severe peripheral arterial occlusion. The presence of external iliac artery occlusion in the present case may allow us to exclude the possibility of hyperperfusion in the leg and exposure to high oxygen concentration.

Prostaglandin E1, heparin-like factors, and microtraumas may also lead to the development of PKS. ${ }^{[6]}$ In the present case, in addition to surgical trauma, saphenous vein removal along with the use of elastic bandages and compression stockings following surgery may have played a role in the development of lesions and PKS in the affected leg. Increased local endothelial growth factors have been reported, particularly in hypoxic conditions. Similarly, products such as heparin, histamine, and tumor necrosis factoralpha released as a result of mast cell degranulation may be responsible for neo-angiogenesis. ${ }^{[7]}$ The total occlusion of the left external iliac artery in our patient may have triggered angiogenesis. Furthermore, the improvement in skin lesions following the opening of the iliac obstruction with a stent bolsters supports for the hypothesis that hypoxic status may have played a role in the etiology of PKS in this patient.

Correction of the underlying vascular pathology in addition to the use of topical steroids is recommended for the treatment of PKS.[3] Supporting this, the resolution of the iliac occlusion in addition to treatment with topical steroids led to a nearly complete recovery of the current patient.

In conclusion, patients with vascular pathologies other than chronic venous insufficiency and arteriovenous malformation undergoing coronary artery bypass grafting-related saphenous vein removal should be carefully evaluated for both typical and unusual skin lesions in the affected leg. Further examination of the lesions with a skin biopsy may be useful for correct diagnosis and treatment, where necessary. Pseudo-Kaposi sarcoma may present as a dermatological condition. However, as a pathology of unknown etiology, pseudo-Kaposi sarcomas should be kept in mind by cardiovascular surgeons, particularly due to its association with vascular diseases and potential for emergence following open heart surgery.

\section{Declaration of conflicting interests}

The authors declared no conflicts of interest with respect to the authorship and/or publication of this article.

\section{Funding}

The authors received no financial support for the research and/or authorship of this article.

\section{REFERENCES}

1. East SA, Lorenz RA, Armbrecht ES. A retrospective review of leg wound complications after coronary artery bypass surgery. AORN J 2013;98:401-12. 
2. Tarhan A, Yapıcı F, Türek O, Yılmaz M, Yapıcı N, Arslan $\mathrm{Y}$, et al. Dropped foot and compartment syndrome in lower extremity after coronary artery bypass grafting surgery. Turk Gogus Kalp Dama 2001;9:171-2.

3. Alshihry H, Chisti MA, Hamadah I. Pseudo-Kaposi sarcoma worsening after leg vein harvest for coronary artery bypass grafting. Ann Saudi Med 2014;34:179-81.

4. Jindal R, De D, Dogra S, Saikia UN, Kanwar AJ. Acroangiodermatitis of Mali in a patient with congenital myopathy. Dermatol Online J 2010;16:4.
5. Smiddy P, Molloy M, Flanagan N, Barnes L. Pseudo-Kaposi's sarcoma: the association of arterio-venous malformations with skin lesions resembling Kaposi's sarcoma. Australas Radiol 2001;45:225-7.

6. Samad A, Dodds S. Acroangiodermatitis: review of the literature and report of a case associated with symmetrical foot ulcers. Eur J Vasc Endovasc Surg 2002;24:558-60.

7. Ikeda, Kano E, Baba S, Suzuki H. Mast cells in pseudoKaposi's sarcoma lesions. J Eur Acad Dermatol Venereol 2001;15:487-9. 